\title{
Generalized Weibull Distribution
}

\section{Revisited}

\author{
Eman M. Sewilam* \\ Department of Statistics, Faculty of Commerce, \\ Al-Azhar University, Girls Branch, Egypt
}

Eman M. Sewilam, assistant Professor (lecturer) of Statistics at Department of applied Statistics, Faculty of Commerce, Al Azhar University, Girls' Branch, Cairo, Egypt. 


\begin{abstract}
In an earlier work by Soleha and Sewilam (2007), an entropy transformation, $\mathrm{g}(\mathrm{x})$, using the reliability function and the cumulative distribution function of a continuous random variable is suggested. It is implemented considering the Rayleigh distribution. The derivative, $g^{\prime}(x)$, gives a peculiar form which is found to be a density function. The present study is a trial to generalize the idea by studying the Weibull distribution. The resulting form is found to be a density function. A statistical inference about the behavior of the derived density function is presented. The main properties of this density function are provided. The behavior of its hazard (failure) rate is investigated. The $\mathrm{r}^{\text {th }}$ moment of a continuous random variable of the derived density function is obtained. The results are verified with the results of the Rayleigh distribution presented by Soleha and Sewilam (2007), considering the Rayleigh distribution as a special case of the Weibull distribution. A peculiar form of the exponential distribution is derived as another special case of the Weibull distribution. The behavior of the derived density function, the reliability function and the hazard (failure) rate has been compared with the behavior of the corresponding well known Weibull distribution.
\end{abstract}




\section{1- Introduction}

The Weibull distribution (WD) has been used for modeling types of "skewedly" distributed lifetime data. The behavior and properties of the Weibul distribution, the reliability and the hazard (failure) rate functions have been discussed. [For more details see Johnson, Kotz and Balakrishnan (3), Lawless (4)].

It is well known that, the Weibull distribution includes the exponential and the Rayleigh distributions as special cases. The exponential distribution is widely used in statistics and reliability analysis as a popular model. But it has a constant failure rate, so it has a limitation to model real data. In the present study, the resulting peculiar form of the exponential distribution indicates an increasing hazard rate before reaching to the constant hazard rate, which exhibit more sensitivity in analyzing lifetime data.

The Weibull distribution presents a convenient way of introducing some flexibility in modeling real data through the shape parameter. The Weibull distribution is commonly used to model systems with monotone failure rates, it might be used to model many real life data, in reliability analysis, that exhibit high initial failure rates (infant mortality), and eventual high failure rates due to aging. The resulting peculiar form of the WD indicates a monotone hazard failure rate which behaves more slowly with time than the hazard rate of the well known Weibull distribution.

The present paper is organized as follows. The next section reviews some properties of the Weibull distribution. Section (3), presents a review of the transformation, $\mathrm{g}(\mathrm{x})$, using the reliability function and the cumulative distribution function of a continuous random variable. Section (4), provides the derived density function of the Weibull distribution, using the transformation, $\mathrm{g}(\mathrm{x})$, which is called "Generalized Weibull Distribution Revisited", (GWDR). The main properties of this density function are investigated. In section (5), a special case of the GWDR is derived when the shape parameter equals one, resulting a peculiar form of the exponential distribution, which is called "Generalized exponential Distribution Revisited", (GEDR). The main properties of this density function are discussed. Section (6), provides a statistical inference about the characteristics of the derived function. The behavior of the derived density function and its hazard (failure) rate are compared with the well known Weibull density function and its hazard (failure) rate. 


\section{2- Main properties of the Weibull distribution}

The probability density function $f(x ; \theta, \beta)$ of the Weibull distribution WD takes the form:

$$
f(x ; \theta, \beta)=\beta \theta X^{\beta-1} \exp \left(-\theta x^{\beta}\right), x \geq 0, \theta>0, \beta>0
$$

where $\theta$ and $\beta$ represent the scale and shape parameters, respectively.

The distribution function is given by :

$$
F(x ; \theta, \beta)=1-\exp \left(-\theta X^{\beta}\right), x \geq 0, \theta>0, \beta>0
$$

The reliability function is given by:

$$
R_{f}(x ; \theta, \beta)=\exp \left(-\theta x^{\beta}\right), x \geq 0, \theta>0, \beta>0
$$

And the hazard function is given as :

$$
h_{f}(x ; \theta, \beta)=\frac{f(x ; \theta, \beta)}{R_{f}(x ; \theta, \beta)}=\beta \theta x^{\beta-1}, x \geq 0, \theta>0, \beta>0
$$

The special case when $\beta=1$ gives the density function and the distribution function of the exponential distribution (ED), respectively, as:

$$
\begin{array}{lll}
f(x)=\theta \exp (-\theta x), & \cdots & x \geq 0, \theta>0 \\
F(x)=1-\exp (-\theta x), & \cdots & x \geq 0, \theta>0
\end{array}
$$

Also, the reliability and the hazard function of the exponential distribution are given respectively, as

$$
\begin{aligned}
& R(x)=\exp (-\theta x), \quad \ldots \quad x \geq 0, \theta>0 \\
& h(x)=\frac{f(x)}{R(x)}=\theta, \quad \ldots \quad \theta>0
\end{aligned}
$$

It is known that the exponential distribution has a constant hazard rate.

\section{3- Constructing the Peculiar form}

The Shannon entropy for the distribution $F$ is defined as:

$H(F)=-\int f(x) \log f(x) d x$ where $f(x)$ denotes the probability density function with respect to the measure (dx) [For more details see Jaynes (2), Akaike (1)].

This idea is used to define a proposed function, $g(x)$, whose derivative $g^{\prime}(x)$ is found to be a density function. The $g(x)$ function is represented by $\mathrm{g}(\mathrm{x})=\mathrm{F}(\mathrm{x})+\mathrm{R}(\mathrm{x}) \ln \mathrm{R}(\mathrm{x}), \mathrm{x} \geq 0$

Where $F(x)$ and $R(x)$ are the distribution and respectively, the reliability function of a continuous random variable $x$.

The present study is a trial to generalize the idea by studying the Weibull distribution. The resulting form is found to be a density function. 
4- Derivation of a peculiar form of the Weibull distribution

Let $F(x)$ and $R(x)$ be the distribution and respectively, the reliability function of a continuous random variable $x$, modeling time to failure of a given component. Consider, the entropy transformation, $g(x)$, being represented by:

$g(x)=F(x)+R(x) \ln R(x), \quad \ldots x \geq 0$
ing that $x$ is a Weibull distributed random variable with density Assuming that $x$ is a wing the distribution function of (2.2) and the function (2.1), then (2.3), the function, $g(x)$, given by (4.1) becomes: reliability function of $(2)=1-\left(1+\theta x^{\beta}\right) \exp \left(-\theta x^{\beta}\right), \quad \ldots x \geq 0, \theta>0, \beta>0$ The first derivative of the function $g(x)$ is given by:

$$
\begin{aligned}
& g^{\prime}(x)=\theta^{2} \beta x^{2 \beta-1} \exp \left(-\theta x^{\beta}\right), \ldots x \geq 0, \theta>0, \beta>0 \\
& \text { first to be a "density" }
\end{aligned}
$$

The resulting function, $g(x)$, is found to be a "density" function that integrates to one. The derived density is called the "Generalized Weibull Distribution Revisited" (GWDR). This density is denoted by $u(x ; \theta, \beta)$ and takes the form:

$u(x ; \theta, \beta)=\theta^{2} \beta x^{2 \beta-1} \exp \left(-\theta x^{\beta}\right), \ldots x \geq 0, \theta>0, \beta>0$

The reliability function of the density $u(x ; \theta, \beta)$ is found to have the form:

$R_{u}(x ; \theta, \beta)=\left(1+\theta x^{\beta}\right) \exp \left(-\theta x^{\beta}\right), x \geq 0, \theta>0, \beta>0$

The factor $\left[\exp \left(-\theta \mathrm{x}^{\beta}\right)\right]$ in (4.5) represents the reliability function, $R_{f}(x ; \theta, \beta)$ of the well known Weibull distribution given in (2.3), So, (4.5) will be rewritten as:

$R_{u}(x ; \theta, \beta)=\left(1+\theta x^{\beta}\right) \cdot R_{f}(x ; \theta, \beta), \ldots \quad x \geq 0, \theta>0, \beta>0$

The factor $\left(1+\theta x^{\beta}\right)$ has a positive value, one can deduce that the reliability function $R_{u}(x ; \theta, \beta)$ of the derived density function decreases with time more slowly than the reliability function $R_{f}(x ; \theta, \beta)$ of the Weibull distribution.

The hazard (failure)rate function of the density $u(x ; \theta, \beta)$ is given by: 


$$
\begin{aligned}
h_{u}(x ; \theta, \beta): & =\frac{u(x ; \theta, \beta)}{R_{u}(x ; \theta, \beta)} \\
& =\frac{\theta^{2} \beta x^{2 \beta-1}}{1+\theta x^{\beta}}, x \geq 0, \theta>0, \beta>0 \\
& =\theta \beta x^{\beta-1}-\left(\frac{\theta \beta x^{\beta-1}}{1+\theta x^{\beta}}\right)
\end{aligned}
$$

The first term $\left(\theta \beta x^{\beta-1}\right)$ of (4.7) represents the hazard function $h_{f}(x ; \theta, \beta)$ of the WD given in (2.4), so, (4.7) will be written as :

$$
h_{u}(x ; \theta, \beta)=h_{f}(x ; \theta, \beta)-\frac{\theta \beta x^{\beta-1}}{1+\theta x^{\beta}}, x \geq 0, \theta>0, \beta>0
$$

Knowing that $(x ; \theta, \beta>0)$, so the second term of (4.8) has a positive value, one can deduce that the hazard rate function $h_{u}(x ; \theta, \beta)$ of the derived density (increases) with time more slowly than the hazard rate function $h_{f}(x ; \theta, \beta)$ of the well known WD.

The special case when $\beta=2$ gives the "Generalized Rayleigh Distribution Revisited" (GRDR) introduced by Soleha and Sewilam [5]

Let $\mathrm{x}$ is a continuous random variable following the derived density $\mathrm{u}$ $(x ; \theta, \beta)$, one can derive the $x^{\text {th }}$ moment $E\left(x^{r}\right)$ as follows:

$$
\begin{aligned}
E\left(x^{r}\right) & =\int_{0}^{\infty} x^{r} \cdot u(x ; \theta, \beta) d x \\
& =\int_{0}^{\infty} x^{r} \cdot \theta^{2} \beta x^{2 \beta-1} e^{-\theta x^{\beta}} d x \\
& =\int_{0}^{\infty} \theta^{2} \beta x^{2 \beta+r-1} e^{-\theta x^{\prime \prime}} d x
\end{aligned}
$$

Integrating (4.9) by parts we obtain; 


$$
E\left(x^{r}\right)=\left[-\theta x^{\beta+r} e^{-\theta x^{\beta}}\right]_{0}^{\infty}+\int_{0}^{\infty} \theta(2 \beta+r-1) x^{\beta+r-1} e^{-\theta x^{\prime \prime}} d x
$$

The first term equals zero and integrating the second term by parts we obtain:

$$
\begin{aligned}
E\left(x^{r}\right)= & {\left[-\frac{(2 \beta+r-1)}{\beta} x^{r} e^{-\theta x^{\beta}}\right]_{0}^{\infty} } \\
& +\frac{(2 \beta+r-1)(\beta+r-1)}{\beta} \int_{0}^{\infty} x^{r-1} e^{-\theta x^{\beta}} d x \\
E\left(x^{r}\right)= & \frac{(2 \beta+r-1)(\beta+r-1)}{\beta} I_{0}
\end{aligned}
$$

Where $I$, is expressed as :

$$
i_{0}=\int_{0}^{\infty} x^{r-1} e^{-\theta x^{\beta}} d x
$$

It is easy to show that $I_{0}$ equals:

$$
I_{0}=\left(\frac{1}{\beta}\right)\left(\frac{1}{\theta}\right)^{\frac{r}{\beta}} \Gamma\left(\frac{r}{\beta}\right)
$$

Using (4.10) and (4.12) one can obtain the $r^{\text {th }}$ moment as:

$$
E\left(x^{\mathrm{r}}\right)=\frac{(2 \beta+r-1)(\beta+r-1)}{\beta^{2}}\left(\frac{1}{\theta}\right)^{\frac{r}{\beta}} \Gamma\left(\frac{r}{\beta}\right)
$$

Putting $(r=1)$ one can obtain the expectation of the GWDR as:

$$
E(x)=(2)\left(\frac{1}{\theta}\right)^{\frac{1}{\beta}} \Gamma\left(\frac{1}{\beta}\right) \text {. }
$$

The special case when $\beta=2$ gives the expectation of the "Generalized Rayleigh Distribution Revisited" introduced by Soleha and Sewilam [5].

5- Derivation of a peculiar form of the exponential distribution 
Knowing that $x$ is a continuous random variable of the derived density $u(x)$, one can derive the $x^{\text {th }}$ moment $E\left(x^{r}\right)$ as:

$$
\begin{aligned}
E\left(x^{r}\right) & =\int_{0}^{\infty} x^{r} \cdot u(x) d x \\
& =\int_{0}^{\infty} \theta^{2} x^{r+1} e^{-\theta x} d x
\end{aligned}
$$

It is easy to show that the $r^{\text {th }}$ moment is given as:

$$
E\left(x^{r}\right)=\left(\frac{1}{\theta}\right)^{r} \Gamma(r+2)
$$

The expectation of the derived density $u(x)$, is obtained (putting $r=1$ ) as:

Note that the the moment of the GEDR of (5.8) is also obtained as a

$$
E(x)=\frac{2}{\theta}
$$

special case of the GWDR by putting $(\beta=1)$ in ( 4.13$)$

In the present section, the behavior of the derived density function, $u(x, \theta, \beta)$, of the GWDR is compared with the corresponding density function, $f(x, \theta, \beta)$, of the well known WD. Also, a comparison of the behavior of the reliability and hazard rate functions of the GWDR and the WD is introduced. The density function $f(x ; \theta, \beta)$ of the WD in (2.1) and the density function $u(x ; \theta, \beta)$ of the GWDR in (4.6) are plotted for different values of the shape parameter $(\beta=0.25,0.5,1,1.5,2,3,4,5)$ and $(\theta=1)$. Also, the reliability and the hazard function of each density are plotted for the same values of $\beta$ and $\theta$ [see Appendix I]. The previous plots are repeated in Appendix II, III for the values $(\theta=0.5,2)$ and the same values of $\beta$. The plots have been done using the mathcad mathematical package 2001 .

The derived density function $u(x ; \theta, \beta)$ is found to be a decreasing function for $(\beta<1)$ and it is a right skewed unimodal function for $(\beta \geq 1)$. The plots indicate that the derived density of the GWDR, $u(x ; \theta, \beta)$ and the Weibull density $f(x ; \theta, \beta)$ are not coinciding.

The reliability function for both the WD of (2.3) and the GWDR of (4.5) are plotted for the same previous values of $\beta$ and $\theta$. These plots 
indicate that the reliability function $R_{u}(x ; \theta, \beta)$ of a component having the derived density GWDR, decreases with time more slowly than the reliability function, $\mathrm{R}_{\mathrm{f}}(\mathrm{x} ; \theta, \beta)$ of a component having the Weibull density function. The investigation of equation (4.6) confirms such relation between the reliability function of the two density functions. So, the derived density of the GWDR may be more convenient for modeling some cases of lifetime data.

The hazard functions of the WD given in (2.4) and of the GWDR given in (4.7) are plotted for the same previous values of $\beta$ and $\theta$. The plots indicate that, both the hazard function $h_{u}(x ; \theta, \beta)$ of the GWDR and the hazard function $h_{f}(x ; \theta, \beta)$ of the WD will have a decreasing function for $(\beta<1)$, but they will have an increasing function for $(\beta>1)$, for all the chosen values of $\theta$. Also, the plots indicate that the hazard (failure) rate $h_{u}(x ; \theta, \beta)$ of a component having the derived density GWDR increases with time more slowly than the hazard (failure) rate of the well known WD. The investigation of equation (4.8) confirms such relation between the hazard (failure) rate of the two density functions. This indicates that the hazard function of the GWDR may be more convenient for modeling some cases of lifetime data.

Recalling that the GEDR is obtained as a special case of the GWDR when the shape parameter $\beta$ equal one. In this case, the plots indicate an increasing hazard rate function of the GEDR, unlike the constant hazard rate of $E D$ for all the chosen values of $\theta$. So, the hazard function of the derived density GEDR seems to be more sensitive for modeling lifetime data than the constant hazard function of the ED. The hazard function of GWDR and the hazard of the WD will have a unimodal functions for ( $\beta$ $>4$ ). The hazard function of the two densities seems to be coincident for ( $\beta$ $\geq 4$ ).

\section{References:}

1. Akaike, H. (1983): "Prediction and Entropy". Technical Summary Report, Mathematics Research Center, University of Wisconsin, Madison, U.S.A.

2. Jaynes, K.T. (1957): Information theory and statistical mechanics. Physical Review, Vol. 106, 620-630. 
3. Johnson, N.L.; Kotz, S. and Balakrishnan, N. (1995): Continuous univariate distributions, vol. 1, Second Edition. John Wiley and Sons Inc., New York.

4. Lawless, J.F. (1985): Statistical models and methods for lifetime data, John Wiley and Sons, New York.

5. Soleha, M.M. and Sewilam, I.A. (2007): Generalized rayleigh distribution revisited, Interstat.

(http:/interstat.statjournals.net/YEAR/2007/articles/0702006.pdf) 


\section{Appendix}


Appendix I $\quad \theta:=1 \quad \beta:=0.2$ :

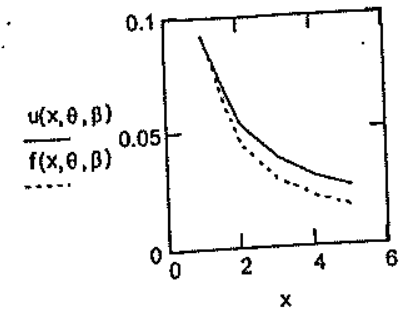

$\dot{\theta}:=1 \quad \beta:=$
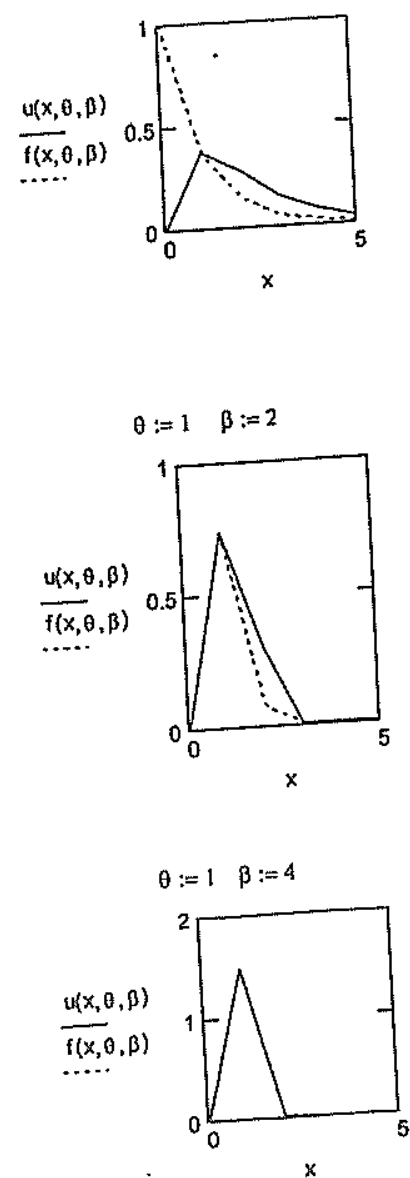

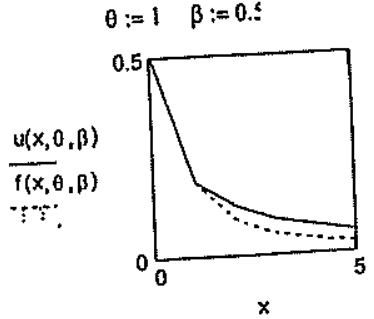

$\theta:=1 \quad \beta:=1.2$
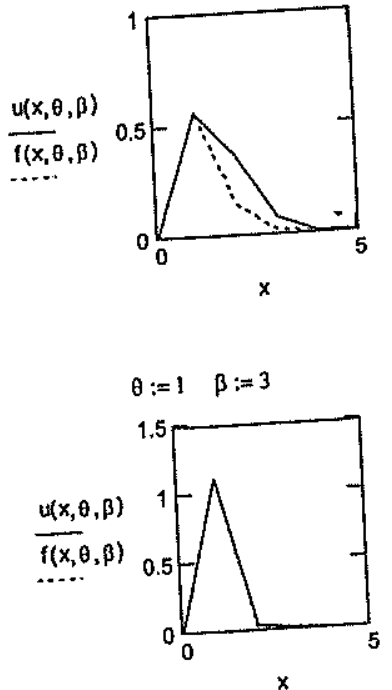

$\theta:=1 \quad \beta:=5$

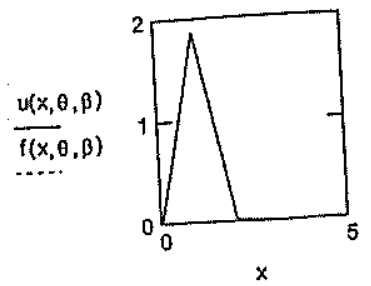

Pils of the densily function of the (WD) and of the (GWDR) for diffarent values of the sitape parameler 

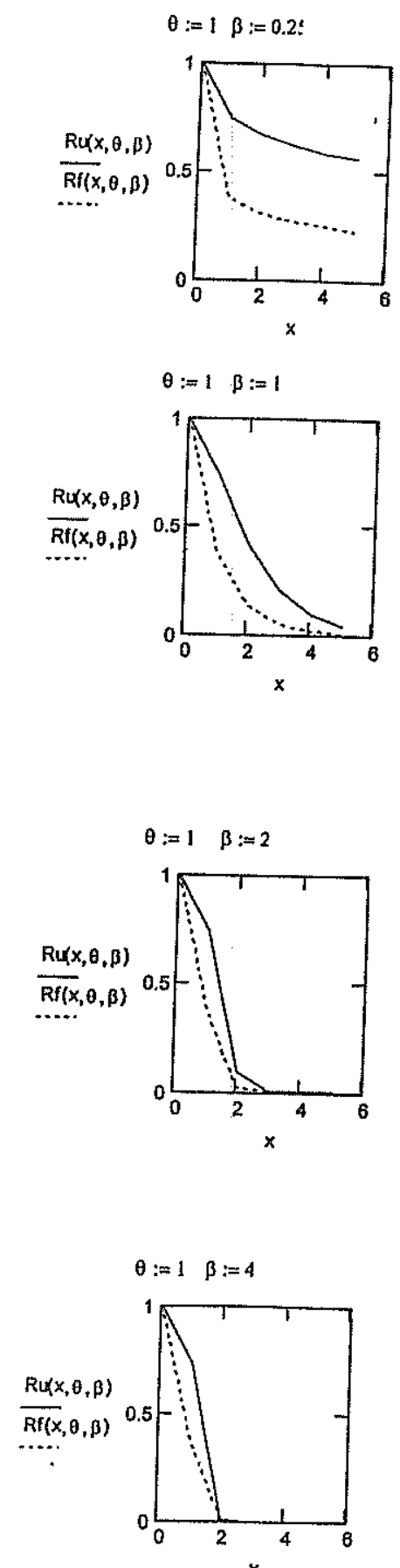

Figure b: Plots of the reliability function of the (WD) and of the (GWDR ) for different values of the shape pardereter.
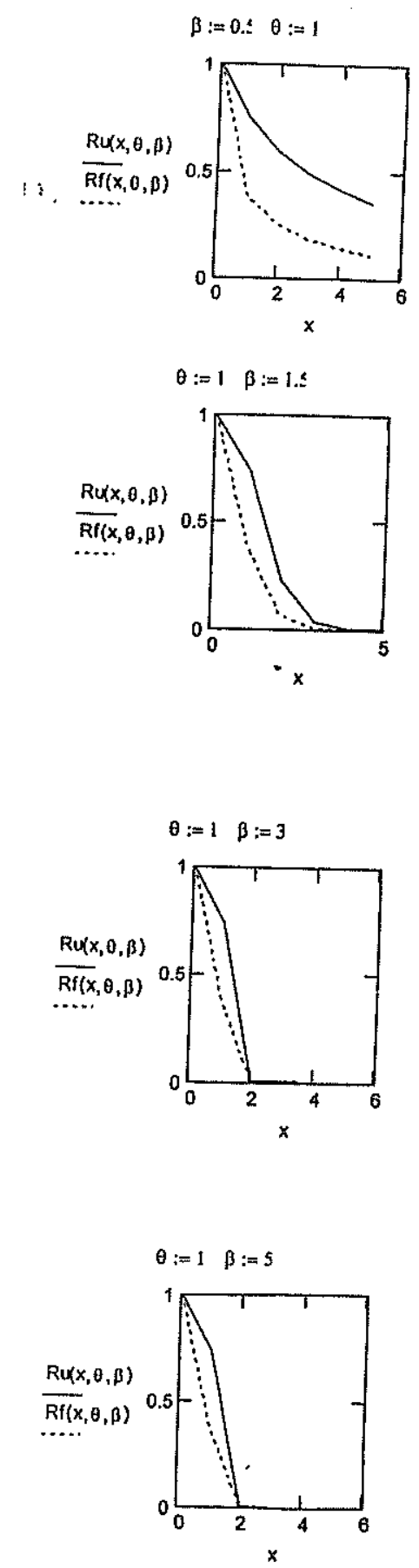


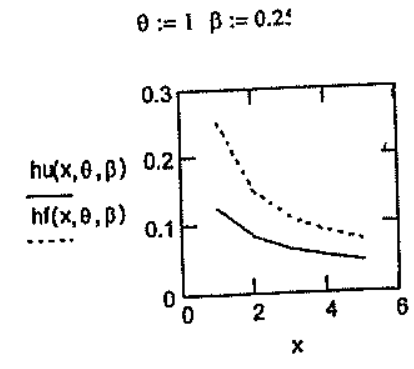

$\theta:=1 \quad \beta:=1$
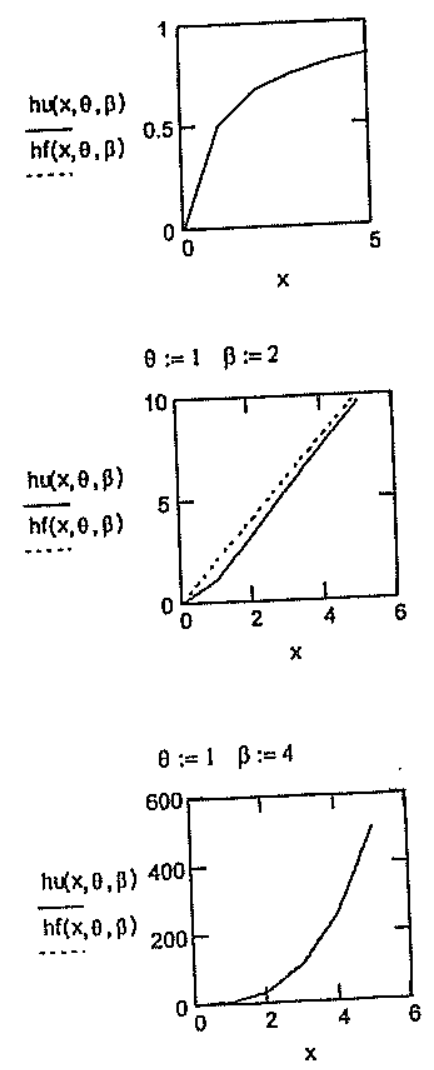
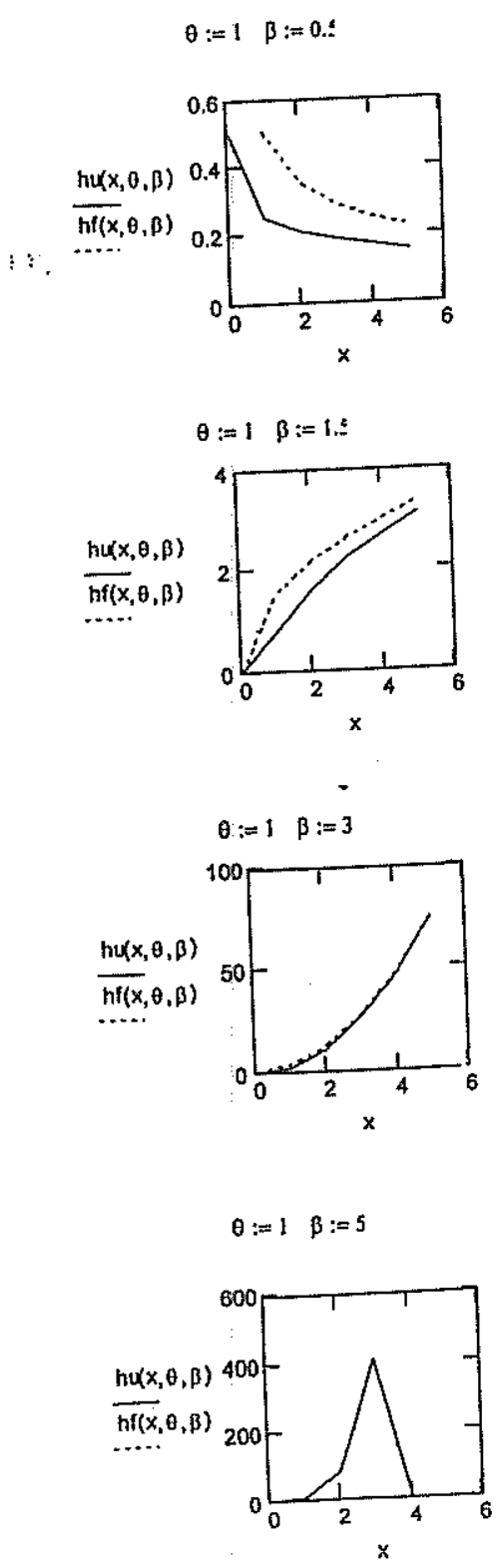

of the (WD) and of the (GWDR) for different values of the shape parameler. 


\section{Apoendix_II}
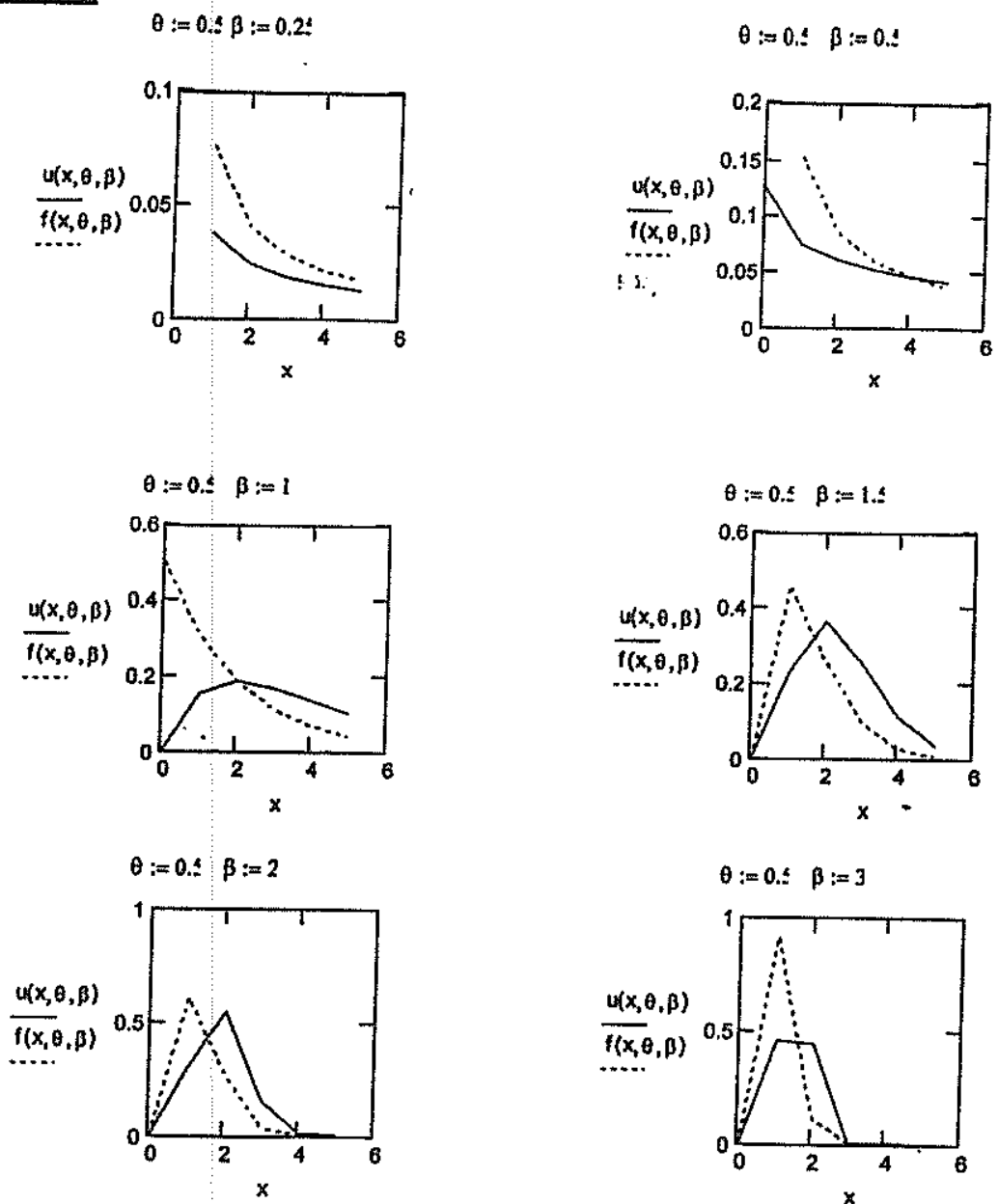

$\theta:=0 . \& \quad \beta:=4$

$\theta:=0 . \leqslant:=5$
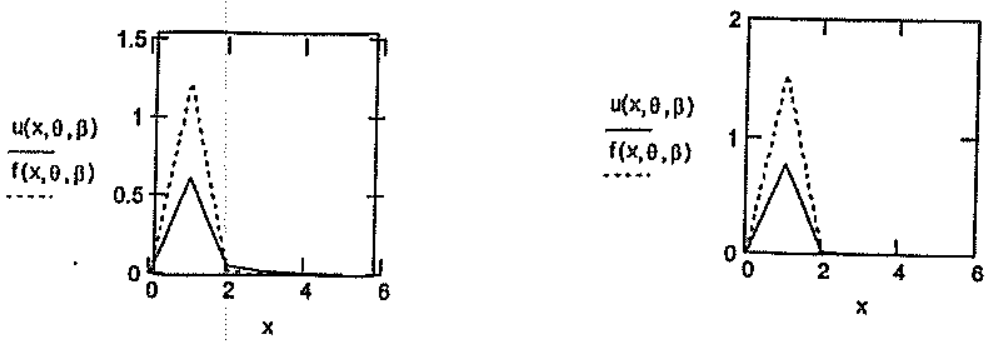

Figure a: Plots of the density function of the (WD) and of the (GWDR) for different values of the shape paraneter. 


Volumes Three and Four New Horizons Journal July \& Octuper Luvo
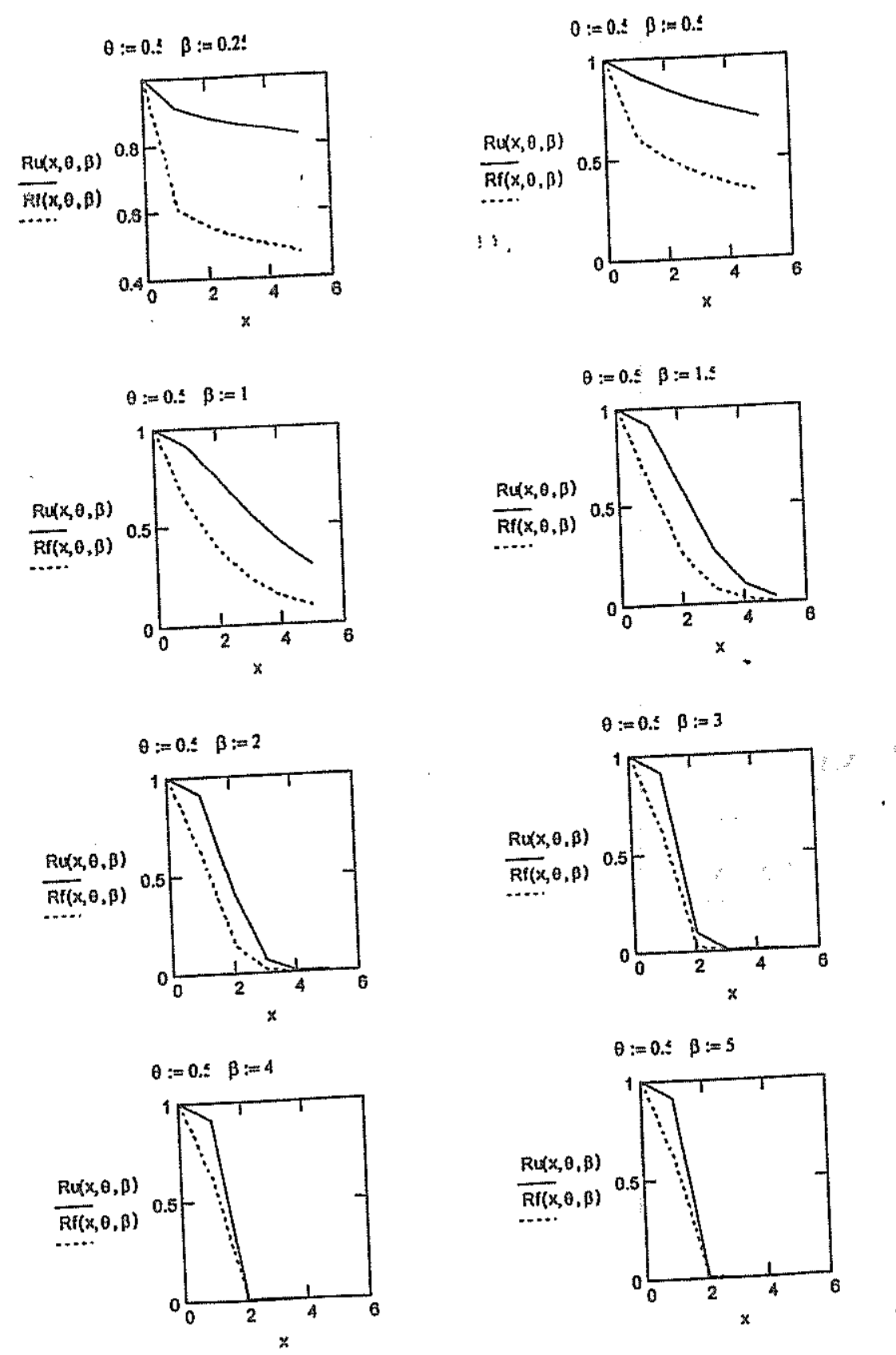

raliabily function of the (WD) and of the (GWDR) for difierent values of the shape paranetor. 

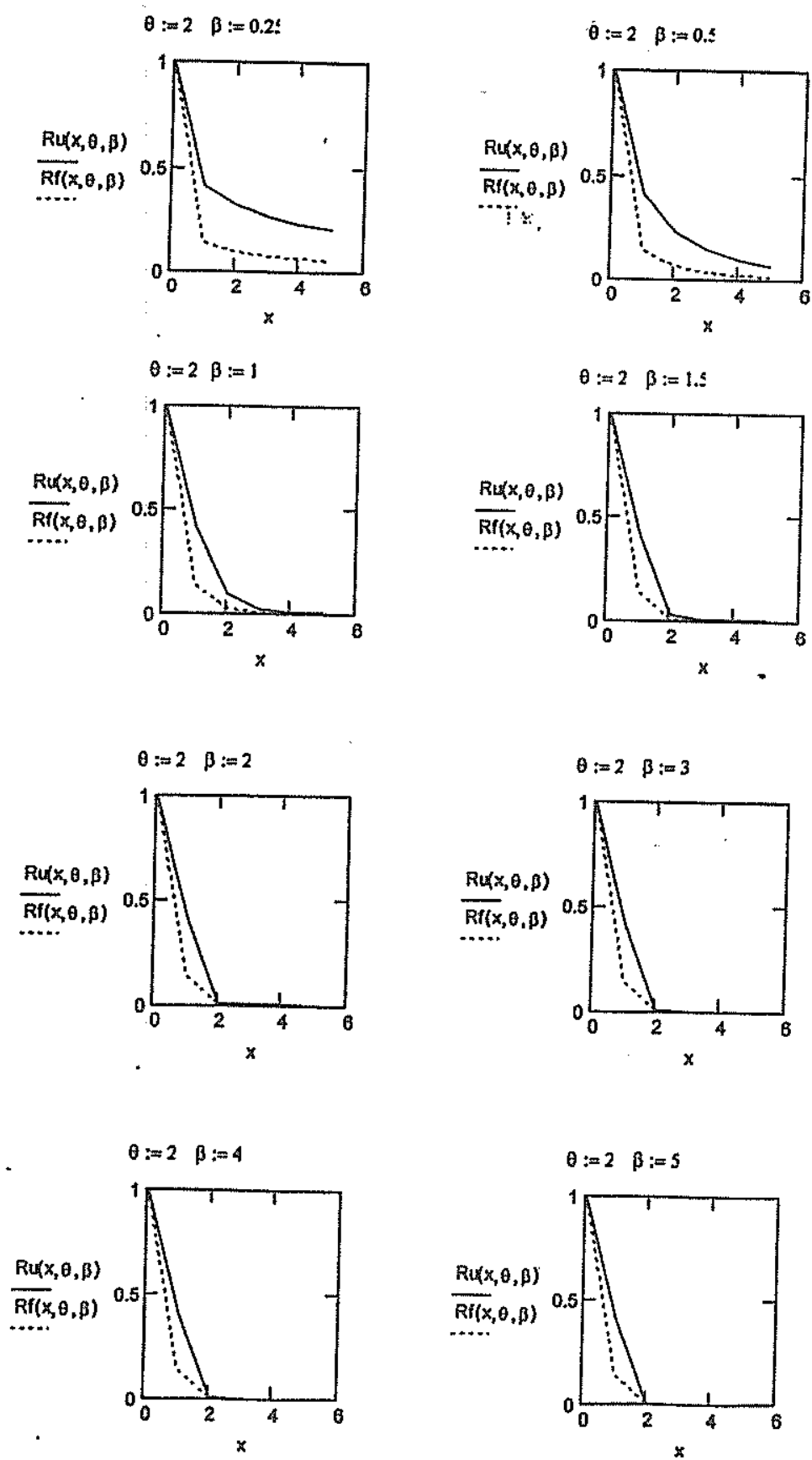

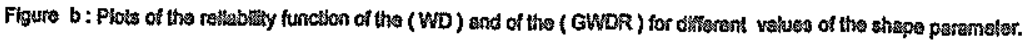



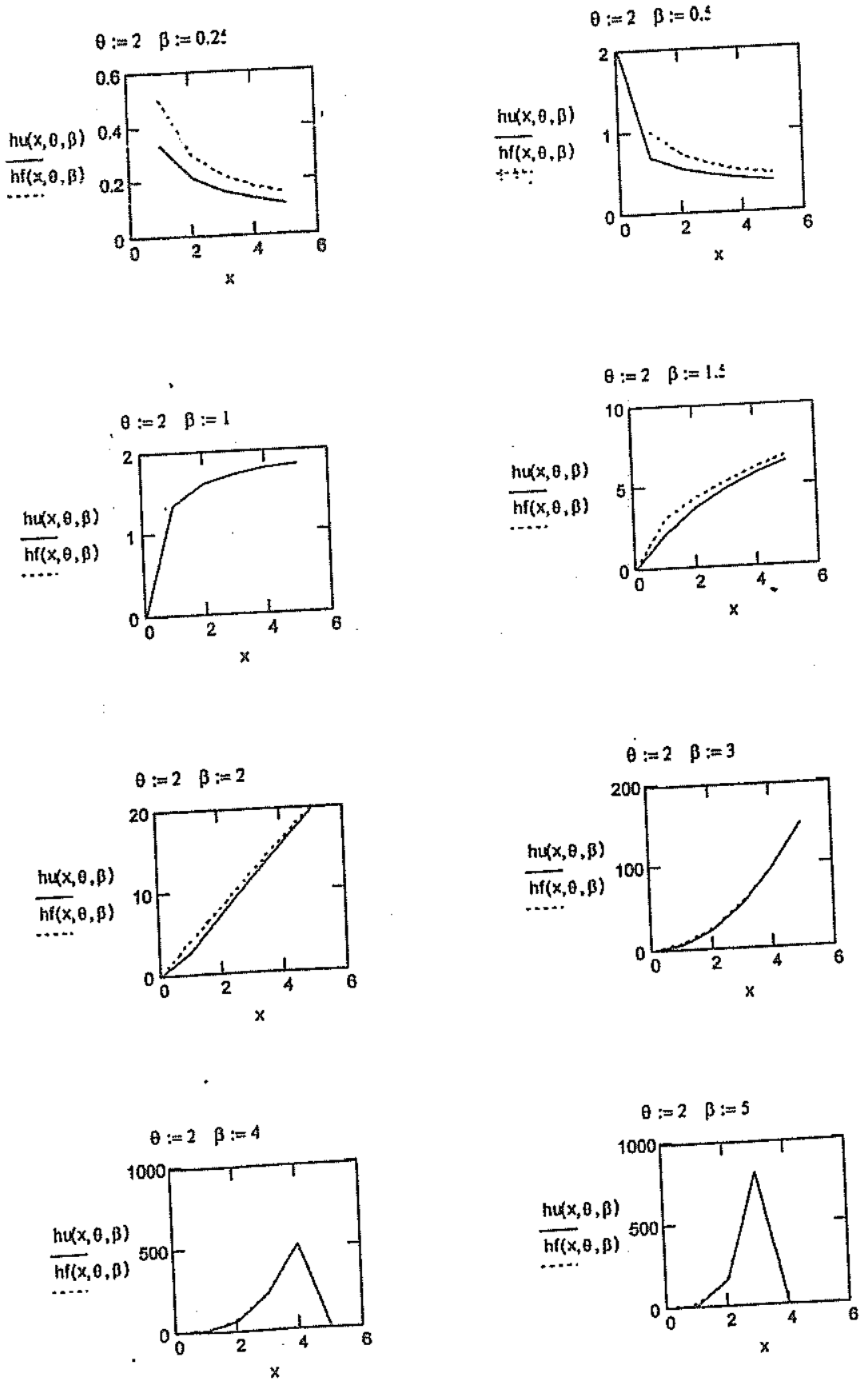

fhe (WD) and of the (GWDR) for different values of the shape partameter. 
of the society's consent for companies to continue surviving. The idea is that when a company's actions have negative impacts on the surrounding community, the public will perceive the existence of this company to be illegitimate, and will react by exercising pressures to embargo the company's products, and to call for government interference. In this case, corporate social accounting disclosures are provided mainly to communicate to the public the company's socially responsible activities in order to justify its continued existence. In this sense, corporations, which are social organizations, depend on society to provide them with legitimacy and support. In this relationship between societies and corporations, the former provide employees, customers, resources, etc., while the latter produce a various social actions in return (O'Dwyer, 2002).

Moreover, O'Dwyer et al. (2005) presented two main opinions about corporations' social disclosure. The first is the practitioners' opinion which suggests that corporate social disclosure is a mechanism to enhance corporate accountability and transparency to most of stakeholders. The second opinion is the academics' who claim that corporate social disclosure is basically produced as a response to the demand of the economically powerful stakeholders.

\section{Previous Research:}

As indicated, much of the research on corporate social accounting disclosures has been carried out in the industrial and more developed counties [e.g., Ernst and Ernst (1972-1978); Bowman and Haire (1976); Trotman (1979); Belkaoui and Karpik (1989); Patten (1991); Ness and Mirza (1991); Gray et al., (1995); Hackston and Milne (1996); Adams et al. (1998); Brown and Deegan (1998); Neu et al. (1998)]. For example, Emst and Emst (1972-1978) series of surveys, which are considered to be among the earliest research to investigate corporate social accounting disclosures, performed a study on the amount of corporate social disclosure in the annual reports of US Fortune 500 companies, and reported an increasing trend of corporate social disclosure by US companies.

In Australia, Trotman (1979) investigated the social accounting disclosure of companies listed on the Sydney Stock Exchange, and found the largest corporations to have a relatively higher level of social accounting disclosure. Hackston and Milne (1996) examined corporate social accounting disclosure practices in New Zealand. They found that 
New Zealand companies make most of their social accounting disclosures on human resources, with lower disclosures on the environment and community themes.

The cornorate sucial accounting disclosure literature also includes studies examining this issue in developing countries. Singh and Ahuja (1983), for example, examined corporate social disclosures on a sample of 40 Indian companies, and found the level of social accounting disclosure to be higher for larger companies. The study also found the type of industry to have an influence on the level of social accounting disclosure, with the highest disclosure levels made by manufacturing firms. Andrew et al. (1989) examined corborate social accounting disclosure in the annual reports of a sample of 119 listed companies in both Malaysia and Singapore, and found that only $26 \%$ of the sampled firms made such a disclosure. They also found that social accounting disclosures were relatively higher in larger firms. In Hong Kong, Lynn (1992) performed a similar examination on a sample of 264 companies, and found that only $6.5 \%$ of the sampled companies made social accounting disclosures in their annual reports. Belal (2001) studied corporate social accounting disclosure practices in Bangladesh, and found that all the sampled companies made some type of social accounting disclosures, and that $97 \%$ of these companies made social disclosures voluntarily. Naser and Abu Baker (1999) and Abu Baker and Naser (2000) articles, which were both conducted in Jordan, are probably the first studies to examine corporate social accounting disclosures in the Arab world. The later, for example, investigated corporate social accounting disclosure using a sample of 143 firms listed on the Amman Financial Market. The study's results indicated that all the sampled firms made some type of social accounting disclosure. Hamid (2004) examined corporate social accounting disclosure in the annual reports of Malaysian banks and financial institutions, and found the level of corporate social accounting disclosure to be higher for larger firms, listed firms (compared to non-listed firms), and for firms that have longer business age. He, however, found insignificant effect of firm's profitability on the level of social disclosure. Ratanajongkol et al. (2006) studied corporate social accounting disclosures of the 40 largest companies in Thailand over the years 1997, 1999 and 2001. They reported an increasing trend of corporate social accounting disclosures by the sampled Thai companies over the examined period, and found Thai 
companies' social disclosures to focus on information about their employee benefits.

\section{METHODOLOGY}

\section{Sample:}

The study sample consists of 27, and 34 annual reports of companies listed in the Kuwait Stock Exchange for the years 2000, and 2005 , respectively. A list of these companies is shown in Table 1. As shown, the companies included in the study sample represent the different sectors of the Kuwait Stock Exchange, including 5 firms from the banking sector, 7 from the investment sector, 8 from the industrial sector, 3 from the food sector, 6 from the real estate sector, 4 from the insurance sector, and 5 from the services sector.

The annual reports used in this study were collected on an ad hoc basis through research assistants who gathered the annual reports by directly contacting the companies' head offices. The study sample includes only listed companies because they are expected to follow better disclosure practices than non-listed companies since they report to a wider rage of constituencies, and are subject to higher levels of regulations. Companies release numerous documents to the public about their socialresponsibility activities (such as, brochures, and press releases). Yet, annual reports are still the most widely used record of companies' social reporting because of their reliability (Tilt, 1994); usefulness (Deegan and Rankin, 1997); ease of access (Woodward, 1998); and regularity (Neimark, 1992). The sample selection was mainly constrained by the availability of the annual reports for the desired years (2000 and 2005).

The 27 (34) companies included in the study sample toresent 31 $\%(22 \%)$ of the total number of companies listed in the Kuwait Stock Exchange in 2000 (2005). As indicated by Gay and Diehl (1992), a sample size of at least 10 percent of the population is deemed to be adequate for descriptive studies. These sampled companies covered the seven sectors listed on the Stock Exchange. 
TABLE 1. The sample of companies by sector

\begin{tabular}{|c|c|c|c|}
\hline Sector & Firm No. & 2000 & 2005 \\
\hline & 1 & $\sqrt{1}$ & $\sqrt{ }$ \\
\hline \multirow{3}{*}{ Banking } & 2 & $\sqrt{1}$ & v \\
\hline & 3 & $\sqrt{3}$ & $y$ \\
\hline & $\begin{array}{l}4 \\
5\end{array}$ & $\begin{array}{l}v \\
y\end{array}$ & NA \\
\hline & 1 & $\sqrt{ }$ & $\sqrt{1}$ \\
\hline \multirow{5}{*}{ Investment } & 2 & $\sqrt{ }$ & $\sqrt{ }$ \\
\hline & 3 & $\sqrt{ }$ & $\sqrt{y}$ \\
\hline & 4 & $y$ & $\begin{array}{l}v \\
y \\
y\end{array}$ \\
\hline & $\begin{array}{l}5 \\
6\end{array}$ & $\sqrt{ }$ & $\sqrt{ }$ \\
\hline & 7 & NA & $\checkmark$ \\
\hline \multirow{7}{*}{ Industrial } & 1 & $\sqrt{1}$ & $\sqrt{1}$ \\
\hline & 2 & v & $\sqrt{v}$ \\
\hline & 3 & v & NA \\
\hline & $\begin{array}{l}4 \\
5\end{array}$ & $\sqrt{ }$ & NA \\
\hline & 6 & $\mathrm{NA}$ & $\sqrt{ }$ \\
\hline & 7 & NA & $y$ \\
\hline & $\frac{8}{1}$ & $\frac{N A}{\sqrt{1}}$ & $\frac{\checkmark}{\mathrm{NA}}$ \\
\hline \multirow{2}{*}{ Food } & $\begin{array}{l}1 \\
2\end{array}$ & j & $\sqrt{ }$ \\
\hline & 3 & $\sqrt{ }$ & $\sqrt{ }$ \\
\hline \multirow{5}{*}{$\begin{array}{c}\text { Real } \\
\text { Estate }\end{array}$} & 1 & $\sqrt{ }$ & $\sqrt{1}$ \\
\hline & 2 & $\mathrm{NA}$ & v \\
\hline & 3 & 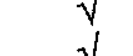 & $\sqrt{ }$ \\
\hline & $\begin{array}{l}4 \\
5\end{array}$ & NA & $\sqrt{ }$ \\
\hline & 6 & $\sqrt{1}$ & $v$ \\
\hline \multirow{4}{*}{ Insurance } & 1 & $\sqrt{ }$ & $\sqrt{ }$ \\
\hline & 2 & $\sqrt{ }$ & $\sqrt{ }$ \\
\hline & 3 & NA & $\begin{array}{l}y \\
y \\
y\end{array}$ \\
\hline & $\frac{4}{1}$ & $\frac{N A}{\sqrt{1}}$ & $\frac{1}{2}$ \\
\hline \multirow{4}{*}{ Services } & 2 & $\checkmark$ & $\sqrt{ }$ \\
\hline & 3 & NA & $\sqrt{ }$ \\
\hline & 4 & NA & $\sqrt{ }$ \\
\hline & 5 & $\frac{\mathrm{NA}}{27}$ & $\frac{v}{34}$ \\
\hline
\end{tabular}




\section{Method:}

A preliminary analysis of the study's sample of annual reports revealed that social accounting disclosures were mainly related to employee benefits, and community services, with little information disclosed about environment. Hence, only three social accounting disclosure categories were considered in this study, and content analysis is performed on materials contained in the annual reports of Kuwaiti companies to extract social information disclosures related to each of these three categories. Such grouping is similar to classifications provided by previous social accounting disclosure research (e.g., Guthrie and Parker 1990; Kuasirikun and Sherer 2004), which categorized corporate disclosure of social information into three similar groupings. The employee benefits category involves disclosures related to those benefits and advantages provided by the company to its employees. The environment category includes disclosures about the company's efforts to preserving the environment. The community involvement category pertains to disclosures about the company's involvement in society and community services.

Accordingly, this research analyzes corporate social accounting disclosure in terms of their theme into employee benefits, environment preservation, and community involvement. In addition, the current study also measures corporate social accounting disclosure in terms of their location in the annual reports (e.g., in chairman's report, operational review, or financial statements). Corporate social accounting disclosure evidence is also classified in terms of the form of presentation into monetary and non-monetary disclosures.

Content analysis is by far the most common method used in prior research to investigate corporate social accounting disclosure (Milne and Adler, 1999). This is true since content analysis is suitable for the appropriate classification and comparison of corporate social accounting disclosure. Previous corporate social disclosure studies have typically used content analysis of firms' annual reports to investigate the extent of corporate social disclosures (e.g., Adams et al., 1998; Bowman and Haire, 1976; Guthrie and Parker, 1990). These studies have aimed at measuring corporate social disclosure by analyzing annual reports of firms in terms of what they reveal (or do not reveal) about their endeavors in the social responsibility arena. Thus, the current study investigates corporate social disclosure in Kuwait by performing content analysis of annual reports of the study's sample of companies. 
The researchers divided the annual reports used in this study into two groups; the 2000 annual reports, and the 2005 annual reports. Each researcher performed the content analysis on one of these two groups as follows: For each comnany, the annual report was read once from cover to cover, and using Hackston and Milne (1996) operational definitions shown in the checklist of corporate social accounting disclosures, any social accounting disclosures found were recorded in a recording sheet. The approach to measuring the social accounting disclosure is, therefore, a dichotomous one in that a company is considered disclosing social accounting information if an item in the checklist is disclosed in the annual renort [3]. The annual reports were read once again to ensure the proper identification and wassification of the social accounting disclosure. Data extracted was then summarized and crosschecked.

\section{RESULTS AND DISCUSSION}

The categories of the social accounting disclosures by disclosing firms in 2000 and 2005 are shown in Table 2. In general, the results indicate that from 2000 to 2005 there was a trend of increased social accounting disclosures by firms listed on the Kuwait Stock Exchange.

$\mathrm{TABL}$ 2. Categories of Social Accounting Disclosures in companies' 2000 and 2005 annual reports.

\begin{tabular}{|l|c|c|}
\hline \multirow{2}{*}{$\begin{array}{l}\text { Categories of } \\
\text { disclosure }\end{array}$} & \multicolumn{2}{|c|}{$\begin{array}{c}\text { Number of Disclosing companies } \\
(\%)\end{array}$} \\
\cline { 2 - 3 } & $\begin{array}{c}2000(27 \\
\text { companies) }\end{array}$ & $\begin{array}{c}2005(34 \\
\text { companies })\end{array}$ \\
\hline $\begin{array}{l}\text { Personnel } \\
\text { benefits }\end{array}$ & $14(51 \%)$ & $22(66 \%)$ \\
\hline $\begin{array}{l}\text { Environment } \\
\text { involvement }\end{array}$ & $0(0 \%)$ & $1(3 \%)$ \\
\hline Total & $18(67 \%)$ & $5(15 \%)$ \\
\hline
\end{tabular}

As shown, about $67 \%$ of the sampled companies (18 firms) had some type of social accounting disclosures in 2000. These disclosures were mainly related to the employee benefits category, while only 4 firms had disclosures about the community involvement category, with no firms 
disclosing any information about the environment in the 2000 annual reports. Table 2 also shows that most social accounting disclosures in 2005 were related to the employee benefit category. In particular, 22 of the 28 disclosing firms (66\%) disclosed information about employee benefits, while only 5 firms disclosed information about their community involvement, and only 1 firm making disclosure about the environment.

The analysis, therefore, indicated that most employee benefits disclosures were related to information about firms' educational support for their employees, and the provision of further training and education for employees through training programs and seminars. One firm from the banking industry, for example, stated:

... [the bank] stepped up its efforts to improve the efficiency of its personnel and enhance their banking capabilities and creating new departments and units as part of the general drive toward modernizing its organization structure. ... [the bank] organized 52 collective programs in which a total of 830 employees participated inside Kuwait, and 110 single training courses in which 180 employees participated. 23 of our employees were delegated to attend 14 specialized courses that were conducted through international institutions outside Kuwait."

(Banking 1, 2000, p.18).

The analysis indicated also that community involvement was another type of corporate social disclosures that was located. This type of disclosure indicates the firm's activities to enhance the welfare of wider community in which the firm is located. For example, the annual report of one of the Kuwaiti banks declared:

"... we recognize that being a good corporate citizen also means being socially responsible by contributing to the welfare and $c$ velopment of the communities we serve. We do this through committing ime, effort an money to various charitable, cultural, social and athletic activities. Education and health also receive special attention for their role in promoting prosperity in our communities."(Banking 3 annual report, 2005, p.7).

Similarly, the annual report of a leading service company stated:

"The company will continue its contribution to society and serve it in various fields. Due to our active involvement, the company's logo and name has become recognized at public and sports events, and conferences. Our solid presence is due to our firm commitment and duty towards society. We view ourselves as a main partner in further developing this society, and we also consider ourselves as one of the national economy's 
anchors as well as a fundamental element of social service in our country." (Services 4, 2005, p. 9)

Table 3 shows the form of the social accounting disclosures included in the annual repouts of 2000 and 2005 . This table indicates that in 2000,9 of the sampled companies (33.3\%) made monetary social accounting disclosures, while $10(37 \%)$ made ron-monetary disclosures. Table 3 also shows that in 2005, 19 of the sampied firms (58\%) made monetary social accounting disclosures, and 14 firms (42\%) made non-monetary disclosures. From table 3 , we can notice, therefore, a slight shift in the form of social accounting disclosure between 2000 and 2005. That is, while nou-monetary disclosures were slightly greater than monetary disclosures in 2000, in 2005 the number of monetary cisclosures was greater than non-monetary ones.

TABLE 3. Form of social accounting disclosures*

\begin{tabular}{|l|c|c|}
\hline \multirow{2}{*}{$\begin{array}{l}\text { Form of } \\
\text { disclosure }\end{array}$} & \multicolumn{2}{|c|}{$\begin{array}{c}\text { Number (\%) of monetary / non- } \\
\text { monetary disclosures }\end{array}$} \\
\cline { 2 - 3 } & $\begin{array}{c}2000(27 \\
\text { companies })\end{array}$ & $\begin{array}{c}2005(34 \\
\text { companies })\end{array}$ \\
\hline Monetary & $9(47.4 \%)$ & $19(56 \%)$ \\
\hline $\begin{array}{l}\text { Non- } \\
\text { monetary }\end{array}$ & $10(52.6 \%)$ & $15(44 \%)$ \\
\hline Total & $19(100 \%)$ & $34(100 \%)$ \\
\hline
\end{tabular}

* Some of the disclosures were displayed in both a monetary and a non-monetary form, thus disclosures displayed are not mutually exclusive.

Table 4 shows the location of the social accounting disclosures included in the annual reports of 2000 and 2005. As Table 4 indicates, most of the social accounting disclosures both in 2000 and 2005 were disclosed in the Chairman's Report and Financial Statements sections of the annual reports. As shown, in 2000, 13 (56.5\%) of the social accounting disclosures were 
presented in the Chairman's Report section, 9 (39.1\%) were disclosed in the Financial Statements section, and only 1 disclosure $(4.3 \%)$ was presented in the Operational Review section. In 2005, 17 (39.5\%) of the social accounting disclosures were made in the Chairman's Report section, $19(44.2 \%)$ were made in the Financial Statement section, and 7 $(16.3 \%)$ were presented in the Operational Review section.

TABLE 4. Location of Social Accounting disclosures*

\begin{tabular}{|l|c|c|}
\hline \multirow{2}{*}{$\begin{array}{l}\text { Location of } \\
\text { disclosure }\end{array}$} & \multicolumn{2}{|c|}{$\begin{array}{c}\text { Number (\%) of locations of social } \\
\text { accounting disclosures }\end{array}$} \\
\cline { 2 - 3 } & 2000 & 2005 \\
\hline $\begin{array}{l}\text { Chairman's } \\
\text { Report }\end{array}$ & $13(56.5 \%)$ & 17 \\
\hline $\begin{array}{l}\text { Operational } \\
\text { Review }\end{array}$ & $1(4.3 \%)$ & 7 \\
\hline $\begin{array}{l}\text { Financial } \\
\text { Statements }\end{array}$ & $9(39.1 \%)$ & $16.3 \%)$ \\
\hline
\end{tabular}

* Some of the disclosures were displayed in more than one location, thus disclosures displayed are not mutually exclusive.

Table 5 shows social accounting disclosures by sectors for 2000 and 2005. From this table, we can notice that, in general, most sectors showed an increase in the number of disclosing firms from 2000 to 2005. This increase is even more evident for the real estate sector, where the number of firms increased from 1 company (25\%) in 2000 to 4 compc ies (80\%) in 2005. Table 5 also indicate that companies in the services sector did not disclose any social accounting information in 2000 , and that only 1 company (20\%) made such a disclosure in 2005.

Table 5: Social Accounting Disclosures by sectors (\% of disclosing firms)

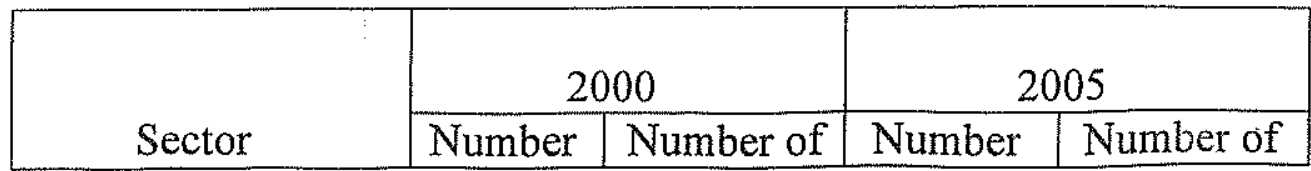


The entropy transformation, $\mathrm{g}(\mathrm{x})$, of (4.1) is implemented considering the exponential distribution with the distribution function:

$$
\mathrm{F}(\mathrm{x})=1-\exp (-\theta \mathrm{x}), \ldots \mathrm{x} \geq 0, \theta>0
$$

and the reliability function:

$$
R(x)=\exp (-\theta x) \quad, \ldots \quad x \geq 0, \theta>0
$$

Then the function, $g(x)$, of $(4.1)$ becomes:

$$
g(x)=1-(1+\theta x) \exp (-\theta x), \ldots x \geq 0, \theta>0
$$

Taking the first derivative of the function $g(x)$ we get:

$$
g^{\prime}(x)=\theta^{2} x \exp (-\theta x), \ldots \quad x \geq 0, \theta>0
$$

The resulting function, $\mathrm{g}^{\prime}(\mathrm{x})$, is found to be a "density" function that integrates to one. The derived density is called the "Generalized Exponential Distribution Revisited" (GEDR). This density is denoted by, $\mathrm{u}(\mathrm{x})$, it takes the form :

$$
u(x)=\theta^{2} x \exp (-\theta x), \ldots \quad x \geq 0, \theta>0
$$

Note that the GEDR is obtained as a special case of the GWDR when the shape parameter $\beta$ equals one.

The reliability function of the GEDR is given by:

$$
R_{u}(x)=(1+\theta x) \exp (-\theta x), \ldots \quad x \geq 0, \theta>0
$$

And the hazard (failure) rate function is given by :

$$
h_{u}(x)=\frac{u(x)}{R_{u}(x)}=\frac{\theta^{2} x}{1+\theta x}=\theta-\frac{\theta}{1+\theta x}, \quad x \geq 0, \theta>0
$$

The first term of (5.5) represents the constant hazard failure rate $h(x)$ of the exponential distribution. Thus Equation (5.5) can be written as :

$$
\mathrm{h}_{\mathrm{u}}(\mathrm{x}) \quad=\mathrm{h}(\mathrm{x})-\frac{\theta}{1+\theta \mathrm{x}}, \ldots \quad \mathrm{x} \geq 0, \theta>0
$$

The special case when $\beta=1$ of the GWDR, the failure rate function $h_{1}(x)$ of (5.6) is obtained. It is an increasing function, unlike, the constant hazard rate of the exponential distribution. This could be proved by showing thet the first derivative $h_{u}^{\prime}(x)>0$ for every $x>0$. The hazard rate function $h_{u}(x)$ will increase to its maximum value $\theta$ as $(x \rightarrow \infty)$, i.e. when $(x \rightarrow \infty)$ the hazard function $h_{u}(x)$ of (5.6) will tend to the constant hazard function, $h(x)$, of $(2.8)$. This indicates that the hazard function $h_{u}(x)$ may be more sensitive for analyzing lifetime data than the constant hazard function $\mathrm{h}(\mathrm{x})$. 


\begin{tabular}{|c|c|c|c|c|}
\hline & $\begin{array}{l}\text { of firms } \\
\text { in sector }\end{array}$ & $\begin{array}{c}\text { (\%) firms } \\
\text { disclosing }\end{array}$ & $\begin{array}{c}\text { of firms } \\
\text { in sector }\end{array}$ & $\begin{array}{c}\text { (\%) firms } \\
\text { disclosing }\end{array}$ \\
\hline Banking & 5 & $4(80 \%)$ & 4 & $4(100 \%)$ \\
\hline Investment & 6 & $4(66 \%)$ & 7 & $5(71 \%)$ \\
\hline Industrial & 5 & $3(60 \%)$ & 6 & $5(83 \%)$ \\
\hline Food & 3 & $2(66 \%)$ & 2 & $2(100 \%)$ \\
\hline $\begin{array}{c}\text { Real } \\
\text { Estate }\end{array}$ & 4 & $1(25 \%)$ & 6 & $4(80 \%)$ \\
\hline Insurance & 2 & $2(100 \%)$ & 4 & $3(75 \%)$ \\
\hline Services & 2 & $0(0 \%)$ & 5 & $1(20 \%)$ \\
\hline Total & 27 & & 34 & \\
\hline
\end{tabular}

\section{CONCLUSION}

This study is an exploratory one on corporate social accounting disclosure practices by firms listed on the Kuwait Stock Exchange, where the main objective is to provide preliminary evidence about social accounting disclosure practices in Kuwait. The study's analysis included examining social accounting disclosures in terms of their theme, location in the annual report, and writing form.

This study contributes to the mostly "western-centric" social accounting literature by shedding lights on the corporate social disclosure practices in Kuwait, a county where, to the authors' best knowledge, research about corporate social accounting disclosure has not been undertaken before.

The results show that, in general, most of the sampled companies did disclose social accounting information in their 2000 and 2005 annual reports. The results also indicate that there was an increasing trend in social accounting disclosures by Kuwait firms from 2000 to 2005 . The study's results also indicate that the majority of social accounting disclosures made by Kuwaiti firms were related to employee benefits, and, to a lesser extent, to community involvement. A somewhat unanticipated result is that only one company had disclosed information about environment conservation efforts. The results also indicated that no particular form of corporate social accounting disclosure (monetary vs. non-monetary) appears to be preferred among Kuwaiti companies, and that most Kuwaiti companies appear to favor disclosing their corporate 
social information in the Chairman's Report and Financial Statements sections of the annual reports.

Due to limited resources, this study has a number of limitations. Firstly, although the study sample of companies covered the seven sectors listed on the Kuwait Stock Exchange, the sample size is still considered small. Such limitation is common in the corporate social accounting disclosure literature however. Another limitation of this study is the short time period examined. Future research could also extend this study by performing analyses over a longer time period.

As indicated, the purpose of this study is to provide exploratory evidence about corporate social accounting disclosure practices in Kuwait. The current study, therefore, should be viewed as a initial step for further research in the area of corporate social accounting disclosure in Kuwait. Future research on this area might examine the effect of certain firm characteristics on the extent and type of corporate social accounting disclosures. Another appealing research would be to perform a comparative examination on corporate social accounting disclosures across countries.

\section{NOTES}

1. Naser and Abu Baker (1999) and Abu Baker and Naser (2000) articles are the only studies we are aware of that examined this issue in the Arab Word. These two papers examined corporate social accounting disclosure practice by Jordanian firms.

2. The corporate practice of social accounting disclosure can be viewed in light of several social theories, including legitimacy theory (see for example O'Dwyer, 2002), stakeholder theory (see Hasnas, 1998; Donaldson and Preston, 1995; Freeman and Reed, 1983), political economy theory (see Benson, 1975; Gary et al. 1996), institutional theory (see DiMaggio and Powell, 1983), and resource dependence theory (see Pfeffer and Salancik, 1978).

3. The use of this dichotomous procedure is an acknowledged limitation since it does not demonstrate how much emphasis is given to each disclosed item, and makes a company that make disclosure of only one social accounting item treated equally as another that makes disclosure of several items. See Hackston and Milne (1996, page 88) for further discussion. 


\section{REFERENCES}

Abu-Baker, N., \& Naser, K. (2000). Empirical evidence on CSD practices in Jordan. International Journal of Commerce and Management, $10,3 \& 4,18-34$.

Adams, C.A., Hill, W., \& Roberts, C.B. (1998). Corporate social reporting practices in Western Europe: legitimating corporate behavior? British Accounting Review, 30, 1-21.

Andrew, B. H., Gul, F. A., Guthrie, J. E., \& Teoh, H. Y. (1989). A Note on Corporate Social Disclosure Practices in Developing Countries: the Case of Malaysia and Singapore. The British Accounting Review, 21, 371-76.

Belal, A. (2001). A study of corporate social disclosures in Bangladesh, Managerial Auditing Journal, 16, 5, 274-289.

Belkaoui, A.R., \& Karpik, P.G. (1989). Determinants of the corporate decision to disclose social information. Accounting, Auditing \& Accountability Journal, 2, 1, 36-51.

Benson, J. K. (1975), The interorganizational network as a political economy. Administrative Science Quarterly, 20, 229-249.

Bowman, E.H., \& Haire, M. (1976). . Social impact disclosure and corporate annual reports. Accounting, Organizations and Society, $1,1,11-21$.

Brown, N., \& Deegan, C. (1998). The public disclosure of environmental performance information: a dual test of media agenda setting theory and legitimacy theory. Accounting and Business Research, $29,1,21-41$.

Burke, R.C. (1984). Decision making in complex times: The contribution of a social accounting. Canada: Society of Management Accountants in Canada.

Deegan, C.M., \& Rankin, M. (1997). The Materiality of Environmental Information to Users of Annul Reports. Accounting, Auditing \& Accountability Journal, 9, 2, 50-67.

DiMaggio, P. \& Powell, W.T. (1993). The iron cage revisited: Institutional isomorphism and collective rationality in organizational fields. American Sociological Review, 48, 2, 147-160.

Donaldson, T., \& Preston, L. (1995). The stakeholder theory of the corporation - concepts, evidence, and implications. Academy of Management Review, 20, 1, 65-92. 
Hamid, F.Z.A. (2004). Corporate social disclosure by banks and finance companies: Malaysian evidence. Corporate Ownership and Control, 1, 4, 118-30.

Hasnas, J. (1998), "The normative theories of business ethnics: a guide for the perplexed": Business Ethics Quarterly, 8, 1, 19-42.

Kuasirikun, N., \& Sherer, M. (2004). Corporate Social Accounting Disclosure in Thailand. Accounting, Auditing \& Accountability Journal, 17, 629-660

Lynn, M. (1992). A Note on Corporate Social Disclosure in Hong Kong. The British Accounting Review, 24, 105-110

Mathews, M.R. (1993). Socially Responsible Accounting. London: Clapman and Hall

Mathews, M.R., \& Perera, M.H.B. (1995). Accounting Theory and Development. Melbourne: Thomas Nelson.

Milne, M. J., \& Adler, R. W. (1999). Exploring the Reliability of Social and Environmental Disclosures Content Analysis. Accounting, Auditing and Accountability Journal, 12, 2, 237-256.

Naser, K., \& Abu Baker, N. (1999). Empirical Evidence on Corporate Social Responsibility Reporting and Accountability in Developing Countries: The Case of Jordan. Advance in International Accounting, 12, $193-226$

Neimark, M.K. (1992). The Hidden Dimensions of Annual Reports: Sixty Years of Social Conflict at General Motors. New York: Markus Wiener.

Ness, K.E., \& Mirza, A.M. (1991). Corporate social disclosure: a note on a test of agency theory. British Accounting Review, 23, 211-17.

Neu, D., Warsame, H., \& Pedwell, K. (1998). Managing public impressions: environmental disclosures in annual reports. Accounting, Organizations and Society, 23, 3, 265-82.

O'Dwyer, B. (2002). Managerial perceptions of corporate social disclosure an Irish Story. Accounting, Auditing and Accountability Journal, 15, 3, 406-436.

O'Dwyer, B., Unermn, J., \& Bradley, J. (2005). Perceptions on the emergence and further development of corporate social disclosure in Ireland. Accounting, Auditing and Accountability Journal, 18, 1 , 14-43.

Parker, L.D. (1986). Polemical themes in social accounting: A scenario for standard setting. Advances in Public Interest Accounting, 1, 67-93. 
Epstein, M.J., \& Freedman, M. (1994). Social Disclosure and the Individual Investor. Accounting, Auditing and Accountability Journal, 7, 4, 94-104.

Ernst and Ernst (1972-1978). Social responsibility disclosure: Surveys of Fortune 500 annual reports. Ohio: Ernst and Ernst.

Freeman, R., \& Reed, D. (1983). Stockholders and stakeholders: a new perspective on corporate governance. Californian Management Review, 25, 2, 88-106.

Gay, L.R., \& Diehl, P.L (1992). Research Methods in Business and Management. New York: Macmillan.

Gary, R. (2002). The social accounting project and accounting organizations and society: privileging engagement, imagination, new accountings and pragmatism over critique? Accounting, Organizations, and Society, 27, 7, 687-708.

Gary, R., Owen, D.L., \& Maunders, K.T. (1987). Corporate Social Reporting: Accounting and Accountability. Hemel Hempstead: Prentice Hall.

Gary, R., Owen, D.L., \& Maunders, K.T. (1988). Corporate Asocial Reporting: emerging trends in accountability and the social contract. Accounting, Auditing and Accountability Journal, 1, 1, 620.

Gary, R., Owen, D.L., \& Maunders, K.T. (1991). Accountability, corporate social reporting, and the external social studies. Advances in Public Interest Accounting, 4, 1, 1-22

Gary, R., Owen, D.L., \& Adams, C. (1996). Accounting and Accountability: changes and Challenges in corporate social and environmental reporting. London: Prentice Hall.

Gray, R., Kouhy, R., \& Lavers, S. (1995). Corporate social and environmental reporting: a review of the literature and a longitudinal study of UK disclosure. Accounting Auditing \& Accountability Journal, 8, 2, 47-77.

Guthrie, J., \& Parker, L.D. (1990). Corporate Social Disclosure Practice: A Comparative International Analysis. Advances in Public Interest Accounting, 3, 159-75.

Hackston, D., \& Milne, M.J. (1996). Some determinants of social and environmental disclosures in New Zealand companies. Accounting, Auditing \& Accountability Journal, 9, 1, 77-108. 